\title{
Construção da identidade religiosa em templos espiritualistas frente à religiosidade cristã: a prática do Espiritismo em Porangatu (Goiás - Brasil)
}

\author{
Léo Carrer Nogueira*
}

\section{Resumo}

Nos últimos anos, a presença das religiões espiritualistas nos espaços urbanos acaba se tornando um fator de instabilidade frente às religiões majoritárias, notoriamente as religiões cristãs. Neste artigo objetivamos analisar estas relações religiosas em um espaço urbano interiorano: a cidade de Porangatu, estado de Goiás. Procuramos analisar a presença do espiritismo kardecista e como ele sofre pressão das religiões cristãs, majoritárias na cidade, o que levam seus praticantes a assumirem uma posição de invisibilidade quanto à sua identificação religiosa por medo de sofrer com atitudes intolerantes. Metodologicamente utilizamos a pesquisa de campo, com entrevista e questionários aplicados a frequentadores do Centro Espírita da cidade, assim como de membros de outras religiões, analisados à luz dos conceitos de Mercado Religioso (PIERUCCI, PRANDI, 1996) e Pluralismo Religioso (HERVIEU-LÉGER, 2008).

Palavras-chave: Espiritismo. Porangatu. Intolerância religiosa. Pluralismo religioso.

\section{Construction of religious identity in spiritualist temples in a Christian society: the practice of Spiritism in Porangatu (Goiás - Brazil)}

\begin{abstract}
In recent years, the presence of the spiritualist religions in urban spaces has become a factor of instability against the majority religions, notably the Christian religions.In this text, we will analyze these religious relations in Porangatu, a small city. We will discuss the presence of Kardecist spiritualism and how it deals with the pressure of the majority Christian religions in the city, leading its adherents to assume a position of invisibility in their religious identification for fear of suffering with intolerant attitudes. Methodologically we used the interviews and questionnaires applied to Spiritists and members of other religions, analyzed with the concepts of Religious Market (PIERUCCI, PRANDI, 1996) and Religious Pluralism (HERVIEU-LÉGER, 2008).
\end{abstract}

Keywords: Spiritism. Porangatu. Religious intolerance. Religious pluralism.

* Doutor em História pela Universidade Federal de Goiás (2017), docente do Mestrado em História da Universidade Estadual de Goiás (PPGHIS-UEG). Email: leo.carrer@gmail.com 


\section{La construcción de la identidad religiosa en los templos espirituaistas frente al cristianismo: la práctica del espiritismo en Porangatu (Goiás - Brasil)}

\section{Resumen}

En los últimos años, la presencia de religiones espiritistas en las ciudades se ha convertido en un factor de inestabilidad frente a las religiones cristianas mayoritarias. En este texto pretendemos analizar estas relaciones religiosas en un espacio interior urbano: la ciudad de Porangatu, estado de Goiás, Brasil. Investigamos la presencia del espiritismo kardecista y cómo está bajo presión de las religiones cristianas, la mayoría en la ciudad, lo que llevó a sus practicantes a asumir una posición de invisibilidad con respecto a su identificación religiosa por temor a sufrir intolerancia. Metodológicamente, utilizamos la investigación de campo, con entrevistas y cuestionarios aplicados a los visitantes del Centro Espírita de la ciudad, así como a miembros de otras religiones, analizados a través de los conceptos de Mercado Religioso (PIERUCCI, PRANDI, 1996) y Pluralismo Religioso (HERVIEU-LÉGER, 2008).

Palabras clave: Espiritismo. Porangatu Intolerancia religiosa. Pluralismo religioso.

\section{Introdução}

Os conflitos religiosos são uma prática que vem crescendo bastante nos últimos anos. Neste artigo, resultado de um projeto de pesquisa desenvolvido, pretendemos analisar práticas de preconceito para com o espiritismo na cidade de Porangatu. Por ser uma religião minoritária na cidade, esta religião sofre um processo de invisibilidade e silenciamento por parte dos segmentos católico-evangélicos, religiões majoritárias.

Assim, procuraremos analisar, na bibliografia teórica, o conceito de intolerância religiosa e como ele é desenvolvido para explicar as disputas em um mercado religioso cada vez mais competitivo e concorrido nas sociedades modernas, para a seguir, tecer algumas análises a respeito da presença da religião espírita numa cidade interiorana ${ }^{1}$. O que pretendemos identificar é como esta religião consegue se inserir e se relacionar em uma dinâmica

\footnotetext{
Para efeito de análise, consideraremos neste artigo as religiões Espiritualistas e Cristãs como opostas historicamente, mesmo sabendo que algumas religiões do primeiro grupo se apropriam de valores cristãos e se afirmam como tal, como é o caso do Espiritismo e de alguns segmentos da Umbanda. O que nos permite fazer esta distinção, no entanto, é o histórico de formação destes grupos religiosos, que, a despeito dos poucos pontos de contato, acabam colocando-as como distantes doutrinariamente umas das outras, especificamente no que tange à forma com que definem a relação do homem com o "sobrenatural" e a possibilidade de comunicação e influência entre estes dois universos: o "terreno" e o "astral".
} 
religiosa na qual mais de $90 \%$ dos habitantes da cidade se declaram como adeptos de algum segmento cristão, católico ou evangélico.

A manutenção de um imaginário negativo a respeito das religiões espiritualistas pode levar seus adeptos a não se assumirem como pertencentes àquela religião, levando a uma invisibilidade e silenciamento destas pessoas quanto à sua opção religiosa. Faremos esta análise numa cidade do interior de Goiás, a cidade de Porangatu, localizada a pouco mais de $400 \mathrm{~km}$ da capital do estado, Goiânia, e que possui pouco mais de 42 mil habitantes, de acordo com o último Censo do IBGE (2010). Nossa opção metodológica foi pela aplicação de questionários com adeptos tanto do espiritismo quanto das religiões cristãs. Os questionários foram aplicados por alunos do curso de História da UEG, Campus de Porangatu, que integravam o projeto de pesquisa de mesmo título e que utilizaram os dados levantados na confecção de seus trabalhos finais de curso, entre os anos de 2013 e 2018, para a seguir fazermos a análise destes dados à luz dos conceitos teóricos desenvolvidos na primeira parte do artigo.

\section{Liberdade religiosa na modernidade}

O conceito de tolerância religiosa está ligado à noção de liberdade religiosa, que remete à própria Declaração Universal dos Direitos Humanos, escrita em 1948. Em seu artigo 18, a Declaração define que:

Todo o homem tem direito à liberdade de pensamento, consciência e religião; este direito inclui a liberdade de mudar de religião ou crença e a liberdade de manifestar essa religião ou crença, pelo ensino, pela prática, pelo culto e pela observância, isolada ou coletivamente, em público ou em particular².

Estas noções influenciaram a construção de grande parte das Constituições Nacionais de vários países do mundo, inclusive a do Brasil, promulgada em 1988. Esta, em seu artigo 5, incisos VI a VIII, define e assegura, a todos os cidadãos do país: liberdade de consciência, de crença, de culto e de organização religiosa (REIMER, 2013, p. 82).

No entanto, mesmo que do ponto de vista jurídico busque-se assegurar o direito à liberdade de culto, é comum presenciarmos cenas de conflitos entre

2 Declaração Universal dos Direitos Humanos, disponível em: https://www.unicef.org/ brazil/pt/resources 10133.htm. Acesso em: 29/05/2018. 
diferentes denominações religiosas. Nos últimos anos, por exemplo, segundo dados do Centro de Promoção da Liberdade Religiosa e Direitos Humanos (Ceplir), as denúncias de discriminação por motivo religioso no Brasil cresceram 4960\% nos últimos cinco anos só no Rio de Janeiro (ROZA, 2017).

Devemos, portanto, buscar compreender as causas que levam a estes casos de intolerância religiosa. Primeiramente devemos compreender como se dá a construção das diferentes identidades sociais e culturais no interior de uma determinada sociedade. Ser pertencente a uma determinada nação é um dos fatores que auxiliam na construção de nossa identidade, mas não é o único. No interior dela, inúmeras outras identidades se formam, a partir do momento que nos identificamos como pertencentes a determinados grupos. $\mathrm{Na}$ medida em que nos identificamos como pertencentes a um grupo, significa dizer que criamos também um processo de diferenciação em relação aos "outros", ou seja, a todos aqueles que não pertencem àquele grupo. É nesta negociação entre "nós" e os "outros" que são construídas nossas identidades sociais.

A construção da identidade é um fenômeno que se produz em referência aos outros, em referência aos critérios de aceitabilidade, de admissibilidade, de credibilidade, e que se faz por meio da negociação direta com outros. Vale dizer que memória e identidade podem perfeitamente ser negociadas, e não são fenômenos que devam ser compreendidos como essências de uma pessoa ou de um grupo (POLLAK, 1992, p. 5).

Stuart Hall (2011), em seu clássico livro sobre "A identidade cultural na Pós-Modernidade" já demonstrou como o processo de descentramento do sujeito tem contribuído para a formação de novas identidades no seio das sociedades nacionais. Como afirmou Pollak (1992), estas identidades já não são essências, mas sim variáveis, cambiáveis e podem ser acionadas de acordo com as diferentes situações do dia-a-dia. Assim também ocorre com as próprias identidades religiosas, especialmente nos casos de religiosidades híbridas, como as de origem africanas.

As próprias religiões africanas, originárias de sociedades ditas "tradicionais", sofreram um longo processo de ressignificações e adaptações no Brasil, dando origem a novas práticas religiosas inteiramente híbridas e que, a partir do século XX, integram-se ao quadro religioso brasileiro como novas opções a disputar fiéis no já concorrido mercado religioso brasileiro (PRANDI, 2004). 
Nas religiões tradicionais, as concepções religiosas apresentam-se de tal modo entrelaçadas aos modos de vida e aos costumes vigentes, de tal modo aderidas ao existente, que "todos os ramos da atividade humana estão como que capturados num círculo de magia simbólica”, conforme palavras de Max Weber. (...) Já nas religiões racionalizadas de Weber, as concepções e valores religiosos são afirmados “à parte”, "acima”, "fora”, “à frente”, "no mais dentro"... e a relação desta forma de religião com a sociedade (já secular) passa de íntima a distante, de espontânea e tranquila a problemática e tensionada (PIERUCCI; PRANDI, 1996, p. 11).

Nas sociedades modernas já não existe mais apenas um único código religioso que norteia nossa vida como acontece nas sociedades "tradicionais". Nestas, todo o aparato político, social e até econômico é influenciado por um código religioso preciso, amparado em crenças que remontam a antigas tradições, consolidadas por anos e anos e passadas de geração a geração. Ao nascer em uma sociedade deste modelo não se pode "escolher" no que acreditar, uma vez que os ditames religiosos estão tão entranhados na vida em sociedade que eles são naturalizados, como se tivesse sido assim desde sempre, o que se constitui em uma tradição. Não se concebe, portanto, a ideia de "trânsito religioso", uma vez que não é admitida a possibilidade da "conversão", conceito tão caro à chamada sociedade "moderna".

É claro que estes dois conceitos, de "tradicional" e "moderno" são utilizados aqui apenas como tipos ideias, polos opostos e abstratos para demarcarmos esta diferenciação entre modelos religiosos em sociedades distintas. Não significa que todas as sociedades possam ser enquadradas "ipsis literis" em um destes dois modelos; pelo contrário, o que encontramos são inúmeras formas diferentes de religiões e tradições que coexistem, mesmo em sociedades pertencentes ao espaço da "modernidade". Um exemplo é o Judaísmo, religião baseada na ancestralidade e na tradição, que originalmente era avessa à ideia de "conversão", mas que, inserida na "modernidade", pode produzir desde novos rearranjos religiosos até o completo abandono de sua religião ancestral para se converter a outro credo, especialmente através dos "casamentos mistos" (SORJ, 2008).

Segundo Bourdieu (2013), esta passagem das religiões de tipo tradicionais, baseadas em uma subordinação ao mundo natural, para religiões do tipo "racionalizadas" estão associadas ao desenvolvimento da vida urbana. A coexistência de diferentes religiões leva à constituição de um verdadeiro "trânsito religioso", processo que tem se intensificado bastante a partir do 
advento da "modernidade" (BERMAN, 1986), especialmente nos séculos XX-XXI. Talvez a principal característica desta modernidade seja o seu rompimento com a "tradição religiosa" como única geradora de sentido. "Na Modernidade, a tradição religiosa não constitui mais um código de sentido que se impõe a todos" (HERVIEU-LÉGER, 2008, p. 34). Isto porque nas sociedades modernas as diferentes estruturas sociais se dissociam e passam a funcionar sob uma lógica própria: política, religião, economia, artes, enfim, cada uma destas tem suas próprias normas de funcionamento. Apesar de todos estes aspectos interagirem entre si, eles não estão mais amarrados por uma ética mágico-religiosa regida pela tradição e ancestralidade, como acontece nas sociedades do tipo tradicional.

Assim, o que esta modernidade tem proporcionado é uma verdadeira proliferação de opções religiosas que estão disponíveis a todos, levando à possibilidade de que os indivíduos tenham maior liberdade para escolher a religião à qual se quer pertencer, pertencer a nenhuma ou até mesmo misturar diferentes crenças. Estas tem sido tendências comuns nas sociedades modernas, levando a fenômenos como da "dupla-pertença", em que fiéis frequentam ao mesmo tempo duas ou mais práticas religiosas (ANTONIAZZI, 2003); ou do "crer sem pertencer", em que indivíduos compõem seu sistema de crença sem necessariamente estarem vinculados a alguma instituição religiosa (HERVIEU-LÉGER, 2008). Outro efeito destes novos rearranjos religiosos típicos da "modernidade" é a concorrência das diferentes instituições religiosas na busca por fiéis, levando ao estabelecimento de um verdadeiro "mercado religioso", onde bens simbólicos e soluções mágico-religiosas são oferecidos aos "clientes", que buscam sempre a melhor "oferta" (OLIVEIRA et al, 2011).

O estabelecimento de um "mercado religioso" pressupõe necessariamente a garantia jurídica da liberdade religiosa e a desregulação estatal, o que promove o florescimento de um pluralismo religioso (MARIANO, 2008). Diante deste pluralismo, o fiel se vê na posição de poder escolher livremente a religião à qual quer pertencer e pode, sempre que mudar de ideia, converter-se a outro credo. A disputa por fiéis se torna, então, fonte de tensões e conflitos entre diferentes denominações religiosas, que devem buscar formas de se reinventar para oferecer diferentes produtos religiosos a quem os procura.

O maior número de grupos religiosos atuantes num determinado território, por sua vez, tende a acirrar a concorrência por sobrevivência e por mercado, 
compelindo-os a mobilizar seus agentes leigos e eclesiásticos, a exigir deles maior compromisso, dedicação e ativismo militante, a estimular o empreendedorismo, a optar por empregar técnicas e estratégias de evangelismo mais atraentes e eficazes e a adaptar-se às demandas de leigos e virtuais adeptos. Quanto maior o pluralismo, postula Stark (1997, p. 17), mais os grupos religiosos se especializarão no atendimento de diferentes demandas. Isto é, o pluralismo e o conseqüente acirramento da competição tendem a aumentar o volume, a diversificar e a melhorar o conjunto de bens e serviços produzidos e ofertados pelos provedores religiosos e, dessa forma, a ampliar a probabilidade de atender aos interesses, às necessidades e às preferências dos distintos nichos e demandas do mercado, resultando na ampliação do recrutamento de novos fiéis (MARIANO, 2008, p. 49).

Este é um dos principais efeitos da pluralidade religiosa nas sociedades modernas: a concorrência entre diferentes agentes na busca por fiéis. A liberdade religiosa, garantida por lei nestas sociedades, acaba possibilitando um trânsito de fiéis, que escolhem suas práticas religiosas de acordo com seus interesses pessoais. Apesar de haver inúmeras pressões envolvidas nesta escolha (familiares, sociais, etc.), já não há mais uma imposição política para que sigam esta ou aquela religião como aconteceu algumas vezes ao longo da história.

Nas sociedades modernas, a crença e a participação religiosas são "assunto de opção pessoal": são assuntos particulares, que dependem da consciência individual e que nenhuma instituição religiosa ou política podem impor a quem quer que seja. Inversamente, a pertença religiosa de um indivíduo e suas crenças não podem constituir um motivo válido para excluí-lo da vida social, profissional ou política, na medida em que elas não põem em questão as regras de direito que regem o exercício dessas diferentes atividades (HERVIEULÉGER, 2008, p. 34).

Como define Hervieu-Léger acima, não se pode, nas sociedades modernas, excluir um indívíduo da vida social ou profissional por sua escolha religiosa. No Brasil, por exemplo, isto é garantido pela Constituição, como já discutimos. No entanto, o que percebemos é que, em relação a algumas denominações religiosas, existem ainda certos preconceitos ou estereótipos formados que levam a atitudes de intolerância religiosa. Estes preconceitos são formados na relação entre diferentes grupos religiosos. Como vimos até agora, na sociedade moderna há a existência de diferentes grupos identitários, o que leva à formação de um mercado religioso extremamente competitivo. 


\section{Intolerância e perseguição religiosa no Brasil}

Esta concorrência religiosa é o que pode levar, em alguns casos, a atitudes extremas de inferiorização e negativização do "outro". Tais atitudes ocorrem, principalmente, entre grupos fundamentalistas. Segundo Ivo Pedro Oro (1996), o fundamentalismo pode ser definido pela leitura literal de um livro religioso, que no caso seria o "fundamento". Aquele fundamento se torna o único código moral válido e aceito pelo grupo, e toda a religião é estruturada em torno dos ensinamentos contidos neste livro sagrado, interpretados de forma quase literal. Como consequência, aqueles que não seguem os fundamentos contidos neste livro além de serem excluídos do grupo, são ainda inferiorizados, criando-se assim uma batalha espiritual entre o Nós e os Outros:

Os outros, a grande maioria, são apóstatas, moralmente pervertidos, arrastados pelo mundo. Enquanto o "nós" (fundamentalistas) constitui o resto fiel aos princípios fundamentais e imutáveis (contidos na Bíblia). (...) Os outros, que não estão no caminho da salvação e (não) aderem à verdade, são o inimigo. (...) Aqueles inimigos são demonizados. Não estão com a verdade. Estão sendo seduzidos e guiados pelo demônio. E como Satanás está solto, é preciso lutar e combater (ORO, 1996, p. 128).

Esta é a raiz do combate existente por parte de algumas denominações neopentecostais a religiões espiritualistas, especialmente as de cunho afro-brasileiro, mas também em relação ao Espiritismo. Para a maior parte dos segmentos evangélicos pentecostais, os outros grupos religiosos são considerados inferiores, "perdidos", e que, portanto, devem ser salvos. Aqueles que não puderem ser salvos devem ser combatidos, pois podem contaminar aos demais com suas visões demoníacas.

A partir desta perspectiva consideramos que a constituição da identidade evangélico-pentecostal predica a violência simbólica - e, vez por outra, física - no trato com o outro na medida em que apregoando a mensagem da Salvação o crente é obrigado a convencer seu interlocutor de sua Perdição. A mensagem da Perdição antecede necessariamente a mensagem da Salvação. No trabalho do convencimento, por meio do discurso, o evangélico-pentecostal realiza a negativação semântica das práticas religiosas que não coadunam com sua visão de mundo. Desse modo a manifestação de intolerância por parte dos evangélicos se configuraria como uma manifestação de sua religiosidade própria e não seria entendida pelo evangélico-pentecostal (agente 
de subalternização) como um ato execrável de desrespeito, mas, antes, como um mandamento basilar que, de acordo com seu modo de ver, quando efetivado, poderá ser a última chance de salvação para o "perdido pecador". O evangélico-pentecostal crê não estar aberto às influências de outros discursos religiosos, sendo que sua postura monotópica em relação à verdade espiritual arrefece o diálogo e a convivência pautada no respeito com outras religiões e formas de religiosidades (RAMOS, 2009, p. 4-5).

A noção de "batalha espiritual" portanto, assentada na leitura bíblica, literal e imutável, é o que move os grupos fundamentalistas pentecostais. Como cristãos, devem exercer diariamente a luta contra as hostes do mal, combatendo o demônio onde quer que esteja e tentando salvar o máximo possível de pessoas. Neste universo espiritual, os outros grupos religiosos são identificados como agentes demoníacos por excelência, especialmente os grupos religiosos espiritualistas, incluindo ai o Espiritismo de origem kardecista e as religiões afro-brasileiras.

Com efeito, os pentecostais teriam sua liberdade religiosa restringida pela Justiça caso não pudessem, por exemplo, considerar demoníacas certas crenças e práticas de seus adversários religiosos (...). O problema é que ao exercê-la livremente nos mais diversos meios de comunicação e espaços públicos e, muitas vezes, de um modo abertamente hostil, esses religiosos protagonizam atos explícitos de "violência simbólica", que estigmatizam, desqualificam e rebaixam moralmente os adeptos dos cultos afro-brasileiros, bem como suas práticas religiosas (MARIANO, 2007, p. 126).

Este tipo de postura por parte de determinados segmentos evangélicos foi inaugurado no Brasil a partir do surgimento do movimento neopentecostal na década de 1980. A mais emblemática desse movimento foi a Igreja Universal do Reino de Deus (IURD), fundada por Edir Macedo no Rio de Janeiro. Uma de suas bandeiras, e talvez a que chamava mais atenção, era o discurso agressivo que seus pastores e bispos adotavam em relação a outras religiões, principalmente as religiões afro-brasileiras (Candomblé e Umbanda), o Espiritismo de origem kardecista e, em menor grau, o Catolicismo e outras denominações evangélicas (FRESTON, 1993).

Alguns destes discursos ficaram consolidados em obras escritas pelo seu principal líder e fundador, o bispo Edir Macedo (2001). No seu livro clássico intitulado "Orixás, Caboclos e Guias: deuses ou demônios?”, o bispo subverte as crenças afro-brasileiras e espíritas mostrando como, ao invés 
de serem guias e protetores, os espíritos, entidades e orixás do Espiritismo, Umbanda e Candomblé respectivamente são na verdade demônios que se apossam de seus fiéis para destruir suas vidas e de seus familiares. Caberia, portanto, a todo fiel da IURD combater estas religiões como uma forma de combater ao próprio demônio representado por elas.

Este tipo de postura pode ser encontrado no interior da própria Igreja. Às terças-feiras, a Igreja se dedica a realizar a Sessão do Descarrego. O nome, que poderia remeter a uma gira de Umbanda, visa aproximar a Igreja de um de seus principais nichos de fiéis: ex praticantes de religiões afro e espíritas. Nestas sessões, fiéis com problemas pessoais são chamados ao púlpito para serem atendidos, onde os "demônios" das religiões afrobrasileiras, representados especialmente por Exus e Pombagiras, se manifestam e são exortados pelo pastor a se retirarem da vida da pessoa. Este tipo de ritualística, que remete bastante aos rituais da Umbanda, marca uma das principais características da IURD: ao mesmo tempo em que demoniza as práticas afro, ela os assimila, reinterpretando-as conforme suas crenças (ORO, 2006).

Este tipo de visão negativa em relação às religiões afro-brasileiras alimenta um imaginário que já duram alguns séculos no Brasil em relação às práticas espiritualistas. A associação dos Exus com o demônio por exemplo já vem de longa data, se iniciando com os viajantes europeus e estadunidenses que passaram pelo continente africano no final do século XIX, e se mantendo ao longo do século XX no Brasil, alimentado especialmente pela religião católica e pela imprensa até a década de 1980 (NOGUEIRA, 2017). Mais recentemente ela tem sido alimentada por algumas denominações pentecostais e neopentecostais, que dão continuidade a séculos de perseguições.

\section{O campo religioso em Porangatu-GO}

A dinâmica do "mercado religioso" é um fenômeno eminentemente urbano, e que pode ser observado especialmente nas grandes metrópoles. O estabelecimento de um grande número de opções religiosas faz com que o mercado seja mais concorrido e acirrado, oferecendo aos fiéis várias possibilidades diferentes de cultos para escolher. Da mesma forma, a impessoalidade que marca as relações entre os habitantes nas grandes cidades está presente também na sua relação com o sagrado. A busca por exclusivismo de algumas denominações religiosas fica menos evidente, na medida em que as pessoas estão mais distanciadas umas das outras. 
O que percebemos é que nas grandes cidades há menos pressões sociais para que se exerça esta ou aquela opção religiosa. Em Goiânia, por exemplo, capital do estado de Goiás, cidade que conta com aproximadamente 1 milhão e trezentas mil pessoas de acordo com o último censo (IBGE, 2010), podemos encontrar um grande pluralismo religioso, com a presença de inúmeras denominações religiosas, desde as religiões cristãs, católicas e evangélicas; espiritualistas, como espiritismo, umbanda e candomblé; comunidades judaicas; islâmicas; diferentes cultos esotéricos; entre outros. Em cidades menores esta dinâmica se altera devido a dois fatores: a maior proximidade entre seus habitantes e as relações pessoais estabelecidas, o que dificultam a constituição de relações de impessoalidade, individualismo e anonimato, marcantes em uma metrópole.

Isto porque na cidade pré-industrial de Sjoberg, por exemplo, ou mesmo na pequena cidade contemporânea, embora as pessoas desempenhem papéis diferentes, estes são, em princípio, conhecidos pelo grupo social inclusivo. A rotina da cidade do interior consiste, exatamente, nisso. As expectativas são cumpridas cotidianamente. Sabe-se que o dono do armazém vai à igreja todo domingo, joga sinuca toda quinta-feira com as mesmas pessoas, é casado, tem tantos filhos etc. Mesmo suas atividades mais clandestinas são, basicamente, controladas. É difícil esconder, por muito tempo, de todos os conhecidos, uma ligação, um hábito etc. Sem dúvida, na metrópole existem pessoas que vivem dentro de esquemas semelhantes em áreas da cidade habitadas por grupos sociais cujo estilo de vida implique nesse tipo de rotina (VELHO, 2000, s/p.).

Este tipo de relação mais próxima e pessoal, típico de algumas pequenas cidades interioranas influencia também na forma como o "mercado religioso" se forma nestas cidades. A existência de menos opções religiosas é o primeiro ponto a ser considerado. Em grande parte das cidades com menos de 50 mil habitantes do estado de Goiás, por exemplo, as únicas religiões presentes são as cristãs: católica e evangélicas. É claro que isto varia e depende de outros fatores, como local em que o município está situado, histórico de formação e sua proximidade com grandes metrópoles, mas no geral há uma menor disponibilidade de opções religiosas, o que implica em uma menor convivência com o diferente.

Em Porangatu, cidade do interior do estado de Goiás, situada no extremo norte do estado, próximo à divisa com Tocantins, podemos ter um exemplo de como esta dinâmica se processa em uma cidade interiorana. Ela 
conta com pouco mais de 40 mil habitantes, podendo ser considerada como uma cidade pequena (IBGE, 2010), e está distante mais de $400 \mathrm{~km}$ da capital do estado, Goiânia. As opções religiosas disponíveis na cidade são poucas. Além das religiões cristãs já citadas, a única religião oficialmente presente segundo o Censo é o espiritismo de origem kardecista (Tabela1).

Tabela 1 - População residente por religião em Porangatu (2010)

\begin{tabular}{l|c|c}
\hline Religião & Número & Porcentagem da População (\%) \\
\hline Católicos & 29.728 & $70,19 \%$ \\
\hline Evangélicos & 9.818 & $23,18 \%$ \\
\hline Espíritas & 319 & $0,75 \%$ \\
\hline População Total & 42.355 & $100 \%$ \\
\hline
\end{tabular}

Fonte: IBGE, 2010.

Não há em Porangatu registros da presença de outras denominações religiosas, apesar de já termos noticiado a presença de membros de outras religiões, como muçulmanos e umbandistas. Estes, no entanto, quando existem são restritos a pequenos grupos familiares, normalmente de pessoas que migraram para a cidade, e ali não encontram meios de externalizar sua fé devido à não existência de templos destas religiões.

Como os únicos templos religiosos existentes na cidade são os demarcados acima (Tabela 1), isto reduz muito o contato dos habitantes com a diversidade religiosa, e fortalece a importância do pertencimento religioso nas relações interpessoais. As comunidades religiosas tendem a se destacar no meio social, e a ser um fator determinante na convivência entre os habitantes. O pertencimento a uma das comunidades religiosas presentes na cidade passa a exercer forte influência na identidade do indivíduo e como ele é visto entre seus pares, diferentemente das grandes cidades em que o fator religioso exerce pouca ou nenhuma influência no relacionamento entre seus habitantes.

No caso da cidade de Porangatu há um predomínio das religiões de cunho cristãs. Católicos e Evangélicos chegam a quase 94\% dos declarantes, segundo o último censo, uma maioria esmagadora frente à única religião distinta presente na cidade: o Espiritismo. Este conta apenas com pouco mais de 300 adeptos declarados, o que corresponde a menos de $1 \%$ da população total da cidade. O único templo espírita existente na cidade é o 
Núcleo Espírita Bezerra de Menezes, fundado em 1963, contando com mais de 50 anos de existência (GOMES; SILVA, 2013). É interessante, portanto, analisarmos como uma religião minoritária como é o caso do Espiritismo em Porangatu se insere na cidade, convivendo com uma maioria de população católica e evangélica.

Por conta deste pouco contato dos habitantes de Porangatu com o diferente, e da baixa quantidade de adeptos do Espiritismo, a visão generalizada que se tem é negativa em relação à presença deste centro espírita na cidade. Esta visão é comprovada pelos próprios frequentadores do Centro Espírita em questão, que atestam por meio de questionários que sofrem ou já sofreram preconceito religioso em relação à sua opção religiosa (Tabela 2).

Tabela 2 -Você acha que existe preconceito com o espiritismo em Porangatu? (2013)

\begin{tabular}{l|l|l}
\hline Resposta & Número & Porcentagem do Total \\
\hline Sim & 16 & $61,54 \%$ \\
\hline Não & 01 & $3,85 \%$ \\
\hline Um pouco & 09 & $34,62 \%$ \\
\hline Total & 26 & $100 \%$ \\
\hline
\end{tabular}

Fonte: GOMES; SILVA, 2013, p. $51^{3}$.

Na tabela acima podemos perceber que a maioria esmagadora dos frequentadores do Centro Espírita entrevistados afirmaram que sentem a existência de pelo menos um pouco de preconceito em relação à sua opção religiosa. Apenas um entrevistado afirmou não existir este preconceito. Isto é sintomático da visão geral que se tem na cidade a respeito desta prática religiosa. Por se tratar de cidade de maioria cristã (católicos e evangélicos), outras denominações religiosas distintas acabam sendo encaradas com desconfiança, seus adeptos não sendo plenamente aceitos como membros do corpo social da cidade.

Isto acaba impactando na forma com que estes indivíduos se posicionam no meio social. Muitos deles preferem não se afirmarem como espíritas no trabalho ou na escola para evitar serem tachados com

\footnotetext{
Os dados apresentados neste artigo foram coletados a partir de um grupo de pesquisas sobre Religião constituído na Universidade Estadual de Goiás, Campus Porangatu, coordenado pelo autor.
} 
denominações pejorativas, levando a uma posição de invisibilidade religiosa. A carga negativa atribuída não só ao espiritismo, como às religiões nãocristãs em geral é sentida por estes indivíduos na forma de preconceitos que, eventualmente, se configuram em atitudes de intolerância religiosa. Vários deles nos relataram já terem sofrido preconceitos diversos, como serem preteridos em cargos no trabalho ou isolados em atividades na escola, e atribuem isso ao fato de conhecerem sua opção religiosa.

O imaginário negativo construído historicamente a respeito das religiões espiritualistas está presente na cidade e pode ser percebido na fala da população em geral. Pudemos percebê-lo ao entrevistarmos frequentadores de templos cristãos de diversas denominações diferentes, tanto católicos quanto evangélicos. Ao serem perguntados sobre sua opinião a respeito das religiões em geral, muitos deles deixaram transparecer uma imagem que diferencia e qualifica as religiões de formas distintas, como podemos perceber na tabela abaixo:

Tabela 3 - Quais religiões são boas e pregam a palavra de Deus? (2018)

\begin{tabular}{l|l|l}
\hline Religião & Número & Porcentagem do Total \\
\hline Católica & 67 & $48,55 \%$ \\
\hline Evangélica & 64 & $46,38 \%$ \\
\hline Espírita & 05 & $3,62 \%$ \\
\hline Outros & 06 & $4,35 \%$ \\
\hline Todas & 11 & $7,97 \%$ \\
\hline Total & 138 & $100 \%$ \\
\hline
\end{tabular}

Fonte: SANTOS; FRANCO, 2018, p. 36.

Ao serem perguntados se consideram que todas as religiões são boas e pregam a palavra de Deus, apenas $8 \%$ afirmaram que todas as religiões se enquadram nesta definição. Enquanto uma média de aproximadamente $50 \%$ consideram as religiões cristãs, católica e evangélica, como boas, apenas pouco mais de 3\% afirmaram considerar o Espiritismo como uma religião boa. Isto demonstra que para a maior parte dos entrevistados, o espiritismo é considerado uma religião má e que não prega a palavra de Deus. Esta percepção está alinhada com o longo histórico de negativizações e perseguições atribuídas ao espiritismo no Brasil ao longo do século XX.

Desde que o Espiritismo chegou no país em 1860, ele teve que enfrentar inúmeros preconceitos e perseguições. O Código Penal de 1890 era 
bastante claro em relação a determinadas atividades religiosas consideradas crimes. Três artigos deste código (art. 156, 157 e 158) tipificavam como crime as práticas do "Espiritismo, magia e seus sortilégios, uso de talismãs e cartomancias"; a "prática ilegal da medicina" e a prática do "curandeirismo", todas elas sujeitas a multas e reclusão (GIUMBELLI, 1997, p. 79). Em todos estes artigos se percebe claramente a tentativa de criminalizar não só o Espiritismo, citado nominalmente em um dos artigos, como também as práticas religiosas de origem africanas que começavam a se espalhar pela capital do país.

Baseado nestes artigos, centros espíritas eram invadidos e revistados pela polícia, seus itens ritualísticos eram destruídos e seus líderes e participantes presos. A nascente Federação Espírita Brasileira (FEB), fundada em 1884 no Rio de Janeiro tinha bastante trabalho para convencer a sociedade à época de que o espiritismo era religião legítima que merecia respeito. Mas de pouco adiantava. Perante os órgãos oficiais e a sociedade em geral, tanto o Espiritismo quanto as religiões afro-brasileiras continuavam sendo vistas de forma pejorativas, criminalizadas e passíveis de sofrer perseguições e reprimendas. Cinquenta anos depois, no código penal de 1940, ainda permaneciam artigos que visavam impedir a prática do espiritismo, embora não mais o citasse nominalmente. Trata-se dos artigos 282, 283 e 284, que tipificavam os crimes de "exercício ilegal da medicina" e de "curandeirismo", que era definido como "inculcar ou anunciar cura por meio secreto ou infalível” (MAGGIE, 1992, p. 47).

Até a década de 1950 o espiritismo ainda sofria os preconceitos da sociedade em geral, e era acusado pela imprensa e pelo catolicismo de ser prática criminosa que devia sofrer com os ditames da lei. Apesar da perseguição se voltar principalmente para as religiões de origem afro, como o Candomblé e a Umbanda, também o espiritismo era considerado religião inferior e que devia ser controlada e exterminada. A construção de um imaginário negativo a respeito da prática espírita está entranhada na história de nosso país, e ainda hoje nós colhemos seus frutos. Muitas denominações evangélicas hoje mantém um discurso de inferiorização e associação da religião Espírita com ações maléficas e demoníacas.

É o caso do discurso da IURD, como já citamos, presente na obra de Edir Macedo (2001, p. 24), que caracteriza o espiritismo como uma religião na qual "os demônios se apresentam como espíritos evoluídos ou ainda em evolução, e que precisam de "doutrina". Para ele, os espíritos 
que se apresentam no espiritismo não passam de demônios que querem dominar a mente de seus adeptos, arruinando com suas vidas. Tais visões, presentes no imaginário de nossa sociedade, são absorvidas pelas populações e disseminadas entre as denominações cristãs de várias formas diferentes, tendo como resultado a construção e manutenção de uma imagem negativa destas práticas religiosas.

Ao serem perguntadas como consideram o Espiritismo, as respostas nos levam a inúmeras interpretações inferiorizantes desta religiosidade, como podemos perceber na tabela 4:

Tabela 4 - Para você o que é o Espiritismo? (2018)

\begin{tabular}{l|l|l}
\hline Resposta & Número & Porcentagem do Total \\
\hline Religião & 33 & $36,67 \%$ \\
\hline Seita & 31 & $34,44 \%$ \\
\hline Macumba & 04 & $4,44 \%$ \\
\hline Culto demoníaco & 18 & $20,00 \%$ \\
\hline Outro & 04 & $4,44 \%$ \\
\hline Total & 90 & $100 \%$ \\
\hline
\end{tabular}

Fonte: SANTOS; FRANCO, 2018, p. 37.

Apenas pouco mais de 35\% dos entrevistados afirmaram considerar a religião espírita como uma Religião. Quase 35\% afirmaram consideraremna como uma seita, termo que historicamente foi utilizado para inferiorizar determinadas práticas não-cristãs, associando-as a uma noção de práticas hereges e depois associadas ao satanismo e à adoração do diabo (SANTOS JÚNIOR, 2004); o termo "macumba", advindo de uma classificação às religiões afro-brasileiras, também é tido como pejorativo, atribuindo às religiões mediúnicas e afro-brasileiras um imaginário racista que as associam a práticas consideradas bárbaras e primitivas (GIUMBELLI, 1997); por fim, o termo "culto demoníaco" é o mais explícito de todos, numa clara tentativa de inferiorizar esta prática religiosa. Somando estes três itens temos um total de quase $60 \%$ de respostas que atribuem à religião espírita noções inferiorizantes, quase sempre associada a ideia de culto demoníaco.

Isto reforça a ideia apresentada pelos frequentadores do espiritismo na cidade de sofrerem preconceito e discriminação religiosa na cidade de 
Porangatu, fazendo com que muitos deles prefiram buscar o anonimato em relação à sua opção religiosa para não sofrer perseguições e discriminações no meio social. Nas conversas e diálogos que mantivemos com os frequentadores ao longo do projeto, muitos alegaram que preferem não se identificar como frequentadores ou adeptos do espiritismo na cidade para evitar serem mal vistos na cidade. Mesmo assim, com a dinâmica de uma cidade interiorana, é difícil para eles manterem sua opção religiosa oculta o tempo todo, o que acaba gerando comentários e atitudes de intolerância, seja de forma velada ou aberta, contra eles.

No âmbito educacional, por exemplo, estas visões se refletem nos conteúdos que devem ser ensinados aos alunos. Ao serem questionados se o ensino religioso nas escolas devia ensinar sobre todas as religiões ou só as cristãs, pouco mais de $50 \%$ optaram por restringir este ensino apenas às religiões cristãs, católica e evangélica, excluindo-se outras denominações religiosas.

Tabela 5 - O Ensino Religioso nas escolas deve ensinar sobre todas as religiões? (2018)

\begin{tabular}{l|l|l}
\hline Resposta & Número & Porcentagem do Total \\
\hline Sim & 41 & $47 \%$ \\
\hline Não, só as cristãs & 47 & $53 \%$ \\
\hline Total & 88 & $100 \%$ \\
\hline
\end{tabular}

Fonte: SANTOS; FRANCO, 2018, p. 36.

$\mathrm{Na}$ prática isto é o que acontece no ensino religioso ministrado na cidade. Em primeiro lugar porque grande parte das escolas particulares da cidade são confessionais, de origem evangélicas. Em segundo lugar, porque mesmo nas que não tem esta origem, o que notamos é que o Ensino Religioso tem se voltado para uma espécie de catequização dos alunos quanto aos valores oriundos das religiosidades cristãs, católica e evangélica (SILVA; MORAIS NETO, 2017). A formação do imaginário cristão, neste caso, passa, portanto, pelo próprio sistema educacional, que adota como padrão uma formação voltada para os valores cristãos, especialmente dos distintos segmentos evangélicos presentes na cidade.

\section{Considerações finais}

Apesar de termos hoje, pela constituição federal, um estado considerado laico, e que prima pela liberdade de culto, na prática o que 
temos é o predomínio de determinados grupos religiosos, que acabam se impondo pelo seu poderio discursivo, político e econômico. É o caso das religiões cristãs como um todo, tanto católica quanto evangélica, que detém hoje um expressivo poder econômico aliado a uma crescente ocupação no campo político, através da eleição de seus representantes para cargos nos poderes legislativo e executivo.

Tudo isto contribui para a veiculação cada vez maior de determinados valores religiosos e sociais, como modelo de família, aceitação ou não de diferentes orientações sexuais, além, é claro, de discursos a respeito da opção religiosa de cada um. Determinadas práticas religiosas são colocadas como perigosas, não compatíveis com a visão religiosa pregada por estes grupos, e assim discriminadas, quando não abertamente, de forma velada. A construção e manutenção de um imaginário negativo a respeito de determinadas religiões acaba sendo reforçado pelas religiões majoritárias, no afã de conseguir mais fiéis no concorrido mercado religioso brasileiro. Deslegitimar o "outro" acaba sendo uma poderosa estratégia de marketing para se vencer a concorrência e trazer o "cliente", conseguindo assim expandir cada vez mais o seu "negócio". Os termos oriundos do nicho empresarial são cada vez mais presentes nestas religiões, que vem acompanhados por uma profissionalização cada vez maior no âmbito do "empreendedorismo" (PIERUCCI; PRANDI, 1996).

O Espiritismo e as religiões afro-brasileiras acabam sofrendo, assim, com a discriminação e preconceito disseminado por este imaginário construído. Embora o espiritismo seja religião que detém também uma influência política e econômica considerável, haja visto serem muitos de seus adeptos oriundos das classes mais altas, em cidades pequenas ela acaba sendo presa mais fácil para o preconceito e a discriminação, em grande parte devido ao seu baixo quantitativo de adeptos e à própria dinâmica destas cidades. Pudemos exemplificar esta tese a partir da análise de um caso específico e que é bastante emblemático de como uma religião espiritualista se insere num mercado religioso no qual predominam as religiões cristãs. Tal dinâmica acaba levando seus adeptos à busca de uma invisibilidade e ocultamento de sua identidade religiosa, para não sofrer com o preconceito e a discriminação existente na cidade.

\section{Referências}

ANTONIAZZI, Alberto. As Religiões no Brasil Segundo o Censo de 2000. In: Revista de Estudos da Religião, No 2, 2003. 
BERMAN, Marshall. Tudo o que é sólido desmancha no ar: a aventura da modernidade. São Paulo, Companhia das Letras, 1986.

BOURDIEU, Pierre. A economia das trocas simbólicas. São Paulo: Perspectiva, 2013.

FRESTON, Paul. Protestantes e política no Brasil: da constituinte ao impeachment. Tese (Doutorado em Ciências Sociais). Campinas-SP: Unicamp, 1993.

GIUMBELLI, Emerson. O cuidado dos mortos: uma história da condenação e legitimação do Espiritismo. Rio de Janeiro: Arquivo Nacional, 1997.

GOMES, Geilany F.; SILVA, Janaína B. Núcleo Espírita Bezerra de Menezes e sua inserção na sociedade de Porangatu-GO. Monografia (Graduação em História). Porangatu: UEG, 2013.

HALL, Stuart. A identidade cultural na pós-modernidade. Rio de Janeiro: DP\&A, 2011.

HERVIEU-LÉGER, Danièle. O peregrino e o convertido: a religião em movimento. Petrópolis-RJ: Vozes, 2008.

IBGE, Cidades. Porangatu. Dados do Censo de 2010. Disponível em: https://cidades.ibge. gov.br/brasil/go/porangatu/panorama. Acesso em: 18/01/2019.

MAGGIE, Yvonne. Medo do feitiço: relações entre magia e poder no Brasil. Rio de Janeiro: Arquivo Nacional, 1992.

MARIANO, Ricardo. Pentecostais em ação: a demonização dos cultos afro-brasileiros. In: SILVA, Vagner G. (Org.). Intolerância religiosa: impactos do neopentecostalismo no campo religioso afro-brasileiro. São Paulo: EdUSP, 2007.

. Usos e limites da teoria da escolha racional da religião. Tempo Social, revista de sociologia da USP, v. 20, n. 2, novembro, 2008.

NOGUEIRA, Léo C. Da África para o Brasil, de Orixá a Egum: as ressignificações de Exu no discurso umbandista. Tese (Doutorado em História). Goiânia: UFG, 2017.

OLIVEIRA, Lívio Luis S.; CORTES, Renan X.; BALBINOTTO NETO, Giácomo. A economia da Religião e seus fundamentos: teste de um modelo de escolha religiosa. Estudos Econômicos, 41(4), outubro/dezembro, 2011.

ORO, Ari P. Neopentecostalismo macumbeiro. Revista USP, n. 68, p. 319-332, dez./fev 2005-2006. São Paulo: USP, 2006.

ORO, Ivo P. O Outro é o Demônio - uma análise sociológica do fundamentalismo. São Paulo: Paulus, 1996.

POLLAK, Michael. Memória e identidade social. Estudos Históricos, v. 05, n. 10. Rio de Janeiro, 1992.

PIERUCCI, Antônio F. PRANDI, Reginaldo. A realidade social das religiões no Brasil religião, sociedade e política. São Paulo: Hucitec, 1996.

PRANDI, Reginaldo. O Brasil com axé: candomblé e umbanda no mercado religioso. Estudos Avançados 18(52), 2004. 
RAMOS, Marcos Paulo M. Cantos de Guerra, parousia e a grande comissão: aspectos da configuração identitária evangélico-pentecostal. Anais do II Seminário de Pesquisa da Pós-Graduação em História UFG/UCG. Goiânia: UFG, 2009.

REIMER, Haroldo. Liberdade religiosa na História e nas constituições do Brasil. São Leopoldo, RS: Oikos, 2013.

RIBEIRO, Wesley S. Intolerância Religiosa e violência frente às práticas religiosas no Brasil no século XXI. Dissertação (Mestrado em Ciências da Religião). Goiânia: PUC-GO, 2017.

ROZA, Gabriele. Destruir terreiros de religiões de matriz africana é a nova "guerra santa" no Brasil. E1 País Brasil. Notícia de 03/11/2017. Disponível em: https://brasil.elpais.com/ brasil/2017/11/03/politica/1509708790_213116.html. Acesso em: 28/11/2017.

SANTOS, Ana Paula A. FRANCO, Euriane T. Intolerância religiosa: o Espiritismo em Porangatu-Goiás. Monografia (Graduação em História). Porangatu: UEG, 2018.

SANTOS JÚNIOR, Reginaldo J. Crítica aos tipos Igreja/Seita para o estudo de grupos religiosos. Revista Eletrônica Correlatio n. 5 - Junho de 2004.

SILVA, Adrielly F. MORAIS NETO, José M. O Ensino Religioso em Sala de Aula: Uma Perspectiva a Partir de Instituições Escolares de Porangatu. Artigo de Conclusão de Curso (Graduação em História). Porangatu: UEG, 2017.

SOUZA, Guilherme M.; FICAGNA, Lais Regina D. Do preconceito à Intolerância religiosa. Revista EDUC-Faculdade de Duque de Caxias, v. 03, n. 02, jul./dez., 2016.

SORJ, B. Conversões e casamento “mistos": a produção de "novos judeus' no Brasil. In: SORJ, B. (Org.). Identidades judaicas no Brasil contemporâneo [online]. Rio de Janeiro: Centro Edelstein de Pesquisas Sociais, 2008.

VELHO, Gilberto. Individualismo, anonimato e violência na metrópole. Horizontes Antropológicos, vol.6, n.13. Porto Alegre, 2000.

Submetido em: 4-7-2019

Aceito em: 7-5-2020 